Bleeding from peptic ulcers and use of non-steroidal anti-inflammatory drugs (NSAIDs) in Romford area compared with local and national prescribing habits

\begin{tabular}{|c|c|c|c|c|c|c|}
\hline \multirow[b]{2}{*}{ NSAID } & \multirow{2}{*}{$\begin{array}{l}\text { No }(\%) \text { of patients with } \\
\text { bleeding peptic ulcers taking NSAID }\end{array}$} & \multirow{2}{*}{$\begin{array}{l}\text { Expected values from } \\
\text { regional prescribing data }\end{array}$} & \multirow{2}{*}{$\begin{array}{l}\text { Mean age } \\
\text { (years) }\end{array}$} & \multirow{2}{*}{$\begin{array}{l}\text { Patients with } \\
\text { ulcer history }\end{array}$} & \multicolumn{2}{|c|}{$\begin{array}{l}\text { No (\%) of prescriptions for NSAIDs } \\
\text { in } 1983 \text { (thousands) } t\end{array}$} \\
\hline & & & & & Great Britain & NE Thames region \\
\hline $\begin{array}{l}\text { Indomethacin } \\
\text { Ibuprofen } \\
\text { Naproxen } \\
\text { Piroxicam } \\
\text { Ketoprofen } \\
\text { Others^ }\end{array}$ & $\begin{array}{rr}9 & (17) \\
2 & (4) \\
6 & (11) \\
14 & (26) \\
8 & (15) \\
14 & (26)\end{array}$ & $\begin{array}{r}10 \cdot 8 \\
8 \cdot 8 \\
5 \cdot 2 \\
6 \cdot 7 \\
2 \cdot 2 \\
19 \cdot 3\end{array}$ & $\begin{array}{l}72 \cdot 1 \\
71 \cdot 0 \\
74 \cdot 5 \\
68 \cdot 6 \\
70 \cdot 6 \\
71 \cdot 6\end{array}$ & $\begin{array}{l}2 \\
1 \\
2 \\
1 \\
0 \\
3\end{array}$ & $\begin{array}{rr}3268 & (17) \\
3544 & (18) \\
2408 & (12) \\
2216 & (11) \\
405 & (2) \\
7683 & (39)\end{array}$ & $\begin{array}{rr}259 & (20) \\
211 & (17) \\
124 & (10) \\
161 & (13) \\
51 & (4) \\
460 & (36)\end{array}$ \\
\hline Total & $53(100)$ & 53 & $71 \cdot 1$ & 9 & $19524(100)$ & $1266(100)$ \\
\hline
\end{tabular}

^Including sulindac, benoxaprofen, phenylbutazone, flurbiprofen, azapropazone, fenoprofen, mefenamic acid. †Source: one in 200 sample, SRI Branch, DHSS.

The Committee on the Safety of Medicines has received 457 reports of upper gastrointestinal bleeding associated with piroxicam since 1970 and 195 associated with ketoprofen since 1971. The corresponding figure for indomethacin since 1965 is 419 (Committee on the Safety of Medicines, personal communication).

We had difficulty locating the data on prescribing frequency given in the table; if such figures (which are Crown copyright) were published problems could be identified early and investigation made. Certainly more detailed studies seem justified.

We have notified the Committee on the Safety of Medicines and Pfizer Limited.

We thank the Medicines Division of the Department of Health and Social Security and $\mathrm{Mr} \mathrm{D}$ Hewitt and Mr I Spooner, of the DHSS, for their help and advice; $M r$ Simon Day for statistical help; and our medical and surgical colleagues for allowing us to study their patients.

1 Fok KH, George PJM, Vicary FR. Peptic ulcers induced by piroxicam. Br Med $\mathcal{f}$ 1985;290:117 2 Ando GA, Lombardino JG. Piroxicam, a literature review of new results from laboratory and clinical studies. Eur f R Reumatol Inflamm 1983;6:3-23.

3 Huskisson EG, Boardman PJ, Burke MJ, et al. UK Hospital and General Practitioner Group-

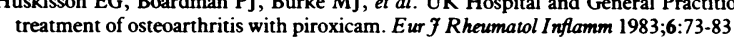

4 Mason J, Bolton MS. A general practice assessment of Alrheumat (ketoprofen) in the treatment of rheumatic conditions. Br J Clin Pract 1977;31:127-34.

(Accepted 12 September 1985)

Department of Gastroenterology, Oldchurch Hospital, Romford, Essex

J D O'BRIEN, BSC, MRCP, research registrar

W R BURNHAM, MD, MRCP, consultant physician/gastroenterologist

Correspondence to: Dr Burnham.

\section{Progressive renal failure in a remnant kidney}

Three quarters nephrectomy in the rat causes glomorulosclerosis in the remnant kidney and progressive azotaemia. ${ }^{\prime}$ Moderate renal failure may start processes that cause further decline of renal function even when the initial mechanism of injury no longer operates and the remaining kidney substance is normal. Similar events may ensue in the human kidney if a substantial proportion of renal tissue is ablated and contribute to the progression of various renal diseases.

We describe a boy aged 3 who lost three quarters of his renal tissue as a result of an accident and ultimately developed heavy proteinuria and declining creatinine clearance. He provided a unique opportunity to observe the effect of the loss of three quarters of the renal substance in man.

\section{Case report}

On 13 May 1964, a boy aged 3 was hit by a van and sustained laceration of the left groin, fractured ribs on the right side, diffuse abdominal tenderness, and shock. He passed a small amount of urine stained with blood, remained oliguric for one week, and required three sessions of haemodialysis. His blood urea concentration fell to $7 \mathrm{mmol} / \mathrm{l}(42 \mathrm{mg} / 100 \mathrm{ml})$ in October 1964. On 9 June 1964 abdominal radiographs showed extensive calcification in the left renal area and upper part of the right kidney, which persisted to a lesser degree in 1969.
Intravenous pyelograms in 1969,1974 , and 1978 showed hypertrophy of the lower pole of the right kidney, which had a normal pelvicalyceal pattern. The left kidney did not function.

Renal function remained stable, and there was no appreciable proteinuria until March 1972, when the plasma creatinine concentration was $100 \mu \mathrm{mol} / 1(1 \cdot 1$ $\mathrm{mg} / 100 \mathrm{ml}$ ), creatinine clearance $44 \mathrm{ml} / \mathrm{min}\left(56.4 \mathrm{ml} / \mathrm{min} / 1 \cdot 73 \mathrm{~m}^{2}\right)$, and 24 hour urine protein $0.82 \mathrm{~g}$ (figure). Modest proteinuria persisted until June 1983, when 24 hour urinary protein was $11 \mathrm{~g}$, plasma creatinine concentration $212 \mu \mathrm{mol} /$ $(2.4 \mathrm{mg} / 100 \mathrm{ml})$, and creatinine clearance $44 \mathrm{ml} / \mathrm{min}\left(36 \cdot 2 \mathrm{ml} / \mathrm{min} / 1 \cdot 73 \mathrm{~m}^{2}\right)$.

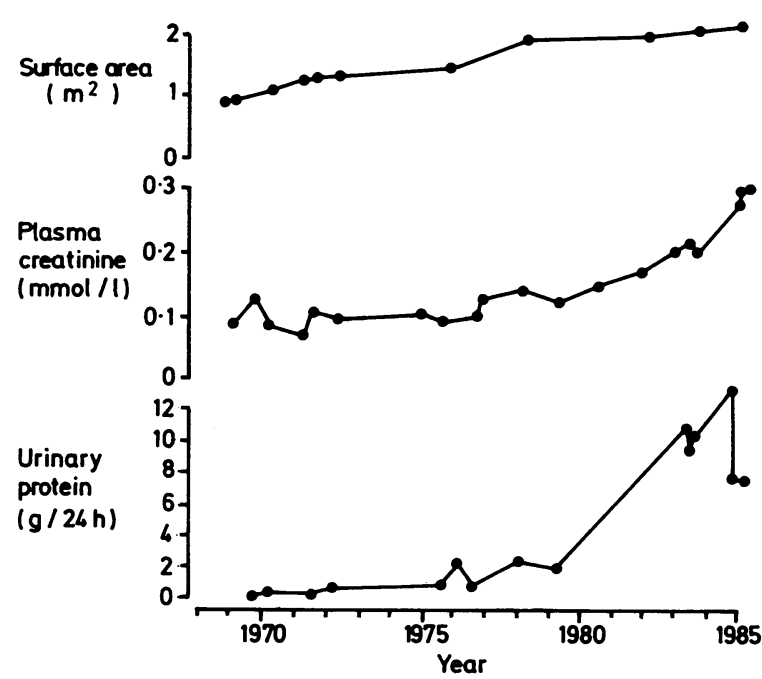

Twenty four hour urinary protein, plasma creatinine concentration, and calculated surface area from 1969 until 1985.

Conversion: SI to traditional units - Plasma creatinine: $1 \mu \mathrm{mol} / \mathrm{l} \approx$ $11 \cdot 3 \mu \mathrm{g} / 100 \mathrm{ml}$.

Hypertension, hyperphosphataemia, hyperuricaemia, and hypoalbuminaemia were not observed during regular follow up, but in December 1984 the plasma creatinine concentration had risen to $330 \mu \mathrm{mol} / 1(3.7 \mathrm{mg} / 100 \mathrm{ml})$ and creatinine clearance fallen to $32 \mathrm{ml} / \mathrm{min}\left(25.5 \mathrm{ml} / \mathrm{min} / 1.73 \mathrm{~m}^{2}\right)$.

An open renal biopsy specimen showed 25 glomeruli, of which two were totally sclerosed, seven showed segmental sclerosis with giant hyaline thrombi and occasional intraglomerular foam cells, and the remainder were large with prominent mesangial regions but otherwise normal. A few tubules were atrophic, mildly dilated, or contained protein casts. The interstitium contained a few smal aggregrates of chronic inflammatory cells. Small arteries and arterioles showed mild focal hyalinisation. Immunofluorescence showed moderate quantities of IgA and $\mathrm{Clq}$ and less quantities of IgM and C3.

\section{Comment}

The lower pole of the right kidney became hypertrophic, and our patient grew normally throughout childhood, during which there was no proteinuria. Mild proteinuria eight years after the accident and heavy proteinuria associated with a decrease of creatinine clearance after 19 years indicated the development of progressive renal disease. Although histology was compatible with idiopathic progressive focal glomerulosclerosis, the rarity of progressive focal glomerulosclerosis and the similarity of the appearances in the three quarters nephrectomised rat suggest that the renal lesion and proteinuria were the result of extensive loss of renal substance.

Hyperphosphataemia, hyperuricaemia, and hypertension may contribute 
BRITISH MEDICAL JOURNAL VOLUME 291 7 DECEMBER 1985

to progressive renal failure. Plasma phosphate and serum uric acid concentrations and blood pressure, however, were always within the normal range, and a renal biopsy specimen showed no evidence of interstitia nephritis and only minimal arteriolar hyalinisation. In the rat extensive rena ablation is followed by increases in glomerular capillary hydraulic pressure, glomerular capillary plasma flow rate, and single nephron glomerular filtration rate, and these changes may eventually cause glomerulosclerosis. Similar processes may have occurred in this case.

Children maintain stable renal function for up to 33 years after unilateral nephrectomy. ${ }^{4}$ Our patient had lost a large proportion of his renal substance 19 years before he developed renal failure, suggesting that the eventual development of glomerulosclerosis in human remnant kidneys depends on both the number of remaining nephrons and the interval since injury.

1 Chanutin A, Ferris ED. Experimental renal insufficiency produced by partial nephrectomy. 1 Control diet. Arch Intern Med 1932;49:767-87.

2 Brenner BM, Meyer TW, Hostetter TH. Dietary protein intake and the progressive nature of kidney disease: the role of haemodynamically mediated glomerular injury in the pathogenesis of progressive glomerulosclerosis in aging, renal ablation and intrinsic renal disease. $N$ Engl f Med
Med progressive gloment

3 Hostetter TH, Olson JL, Rennke HG, Venkatachalam MA, Brenner BM. Hyperfiltration in remnant nephrons: a potentially adverse response to renal ablation. Am J Physiol 1981;241: F85-93

4 Robitaille P, Mongeau J-G, Lortie L, Sinnassamy P. Long-term follow-up of patients who underwent unilateral nephrectomy in childhood. Lancet 1985; ;:1297-9.

(Accepted 4 September 1985)

Renal unit, Manchester Royal Infirmary, Manchester M13 9WZ

L R SOLOMON, MRCP, lecturer in medicine

N P MALLICK, FRCP, consultant physician

Department of Pathology, Manchester University, Manchester M13

W LAWLER, MRCPATH, senior lecturer in pathology

Correspondence and requests for reprints to: Dr Solomon.

\section{Metronidazole and Indian kala-azar: results of a clinical trial}

Visceral leishmaniasis is a disease of global importance, yet the choice of drugs available for its treatment is severely limited; so far there has been no satisfactory alternative to pentavalent antimony. Metronidazole is a time honoured drug with a wide margin of safety and a wide range of antiprotozoal activity. Anecdotal reports suggest that it may be effective in visceral leishmaniasis. ${ }^{12}$ We report our experience with this drug in Indian kala-azar.

\section{Patients, methods, and results}

We studied five men and five women with the disease. Their mean age was $26 \cdot 7$ (SD 9.0) years and mean weight $37.5(\mathrm{SD} \mathrm{5.0}) \mathrm{kg}$. After a thorough clinical examination and routine investigations bone marrow was obtained by sternal or iliac crest puncture and smears examined for amastigotes of Leishmania donovani.
Only parasitologically confirmed cases were studied. Patients with complications such as pulmonary tuberculosis, jaundice, and cardiac or renal failure were excluded, as were those who had ever received antimonials or any other specific reatment for kala-azar.

Each patient was given metronidazole for 12 days $-25 \mathrm{mg} / \mathrm{kg}$ daily by intravenous infusion for five days followed by $40 \mathrm{mg} / \mathrm{kg}$ daily by mouth in four divided doses for seven days. Patients were assessed at regular intervals and any who did not show a satisfactory clinical response within two weeks were switched to antimony. In other cases the final assessment was made at the end of four weeks, when the bone marrow was also re-examined. The duration of follow up ranged from one to 10 months.

Student's $t$ test for paired data was used to compare pretreatment and posttreatment values.

Six patients showed both clinical and parasitological evidence of cure and remained well for up to 10 months (table). Only two patients did not respond clinically. One patient (case 5) showed clinical but not parasitological evidence of cure, and another patient (case 7) withdrew from the trial just when her temperature had touched almost normal. Possibly a longer period of treatmen might have succeeded in these last two cases. There were no appreciable side effects in any patient.

\section{Comment}

In six out of these 10 cases the results may be said to have been excellent, while two might be given the benefit of doubt; two cases were clear treatment failures.

Though experimental and in vitro studies ${ }^{34}$ must have dampened the enthusiasm of many workers, we decided to pursue this study as clinical results do not always conform to experimental findings. We are reasonably gratified by the results.

In view of the remarkable safety of metronidazole we suggest that it is worth a trial as a first line drug in visceral leishmaniasis; if treatment fails the patient may easily be switched to pentavalent antimony. The optimum dose, duration of treatment, route of administration, and mode of action, however, remain to be defined.

We are grateful to $M / S$ Unichem Laboratories Ltd for liberal supplies of metronidazole and to Mr Amar Nath Jha for typing and retyping the manuscript.

1 Murphy KJ, Borg AC. Co-trimoxazole for systemic leishmaniasis. Lancet 1981;i:323-4.

2 Masramon JC, Aubia J, Lloveras J, Llorach I, Llorach M. Co-trimoxazole for leishmaniasis-or metronidazole? Lancet 1981;i:669.

3 Keithly JS, Langreth SG. Inefficacy of metronidazole in experimental infections of Leishmania donovani, L mexicana and Trypanosoma brucei brucei. Am F Trop Med Hyg 1983;32:485-96. 4 Neal RD, Croft SL. An in vitro system for determining the activity of compounds against the intracellular amastigote form of Leishmania donovani. I Antimicrob Chemother 1984;14:463-75.

(Accepted 27 August 1985)

Departments of Medicine and Microbiology, Darbhanga Medical College and Hospital, Darbhanga (Bihar) 846003 , India

MOHAN MISHRA, MD, FRCPED, professor of medicine

$B$ D THAKUR, MD, resident medical officer

MAHESHWAR CHOUDHARY, MD, associate professor of microbiology

Correspondence to: Professor Mishra.

\begin{tabular}{|c|c|c|c|c|c|c|c|c|c|c|c|}
\hline & \multicolumn{10}{|c|}{ Case No } & \multirow[b]{2}{*}{ Mean } \\
\hline & 1 & 2 & 3 & 4 & 5 & 6 & 7 & 8 & 9 & 10 & \\
\hline $\begin{array}{l}\text { Liver enlargement }(\mathrm{cm}) \text { : } \\
\text { Before treatment } \\
\text { After treatment }\end{array}$ & $\begin{array}{l}2 \\
0\end{array}$ & $\begin{array}{l}3 \\
0\end{array}$ & $\begin{array}{l}7 \\
3\end{array}$ & $\begin{array}{l}4 \\
0\end{array}$ & $\begin{array}{r}10 \\
3\end{array}$ & $\begin{array}{l}6 \\
4\end{array}$ & $\begin{array}{l}7 \\
1\end{array}$ & $\begin{array}{l}0 \\
0\end{array}$ & $\begin{array}{r}11 \\
6\end{array}$ & $\begin{array}{l}5 \\
4\end{array}$ & $\begin{array}{l}5 \cdot 5 \\
2 \cdot 1^{*}\end{array}$ \\
\hline $\begin{array}{l}\text { Spleen enlargement }(\mathrm{cm}) \text { : } \\
\text { Before treatment } \\
\text { After treatment }\end{array}$ & $\begin{array}{l}9 \\
2\end{array}$ & $\begin{array}{l}5 \\
2\end{array}$ & $\begin{array}{l}7 \\
3\end{array}$ & $\begin{array}{l}4 \\
0\end{array}$ & $\begin{array}{r}11 \\
4\end{array}$ & $\begin{array}{l}17 \\
15\end{array}$ & $\begin{array}{l}5 \\
2\end{array}$ & $\begin{array}{l}8 \\
4\end{array}$ & $\begin{array}{l}7 \\
0\end{array}$ & $\begin{array}{l}5 \\
3\end{array}$ & $\begin{array}{l}7 \cdot 8 \\
3 \cdot 5^{\star}\end{array}$ \\
\hline $\begin{array}{l}\text { Total leucocyte count }\left(\times 10^{9} /\right) \text { : } \\
\text { Before treatment } \\
\text { After treatment }\end{array}$ & $\begin{array}{l}1.4 \\
3.9\end{array}$ & $\begin{array}{l}2.5 \\
5.5\end{array}$ & $\begin{array}{l}2 \cdot 7 \\
6 \cdot 7\end{array}$ & $\begin{array}{l}3 \cdot 8 \\
6 \cdot 6\end{array}$ & $\begin{array}{l}2.5 \\
5.2\end{array}$ & $\begin{array}{l}1.9 \\
1.8\end{array}$ & $\begin{array}{l}2 \cdot 2 \\
3 \cdot 3\end{array}$ & $\begin{array}{l}4.6 \\
8.0\end{array}$ & $\begin{array}{r}5 \cdot 3 \\
10 \cdot 1\end{array}$ & $\begin{array}{l}5 \cdot 2 \\
5.7\end{array}$ & $\begin{array}{l}3 \cdot 21 \\
5.68^{\star}\end{array}$ \\
\hline $\begin{array}{l}\text { Haemoglobin }(\mathrm{g} / \mathrm{/}) \\
\text { Before treatment } \\
\text { After treatment }\end{array}$ & $\begin{array}{l}64 \\
86\end{array}$ & $\begin{array}{r}88 \\
110\end{array}$ & $\begin{array}{l}102 \\
115\end{array}$ & $\begin{array}{r}90 \\
116\end{array}$ & $\begin{array}{l}60 \\
70\end{array}$ & $\begin{array}{l}52 \\
72\end{array}$ & $\begin{array}{r}78 \\
100\end{array}$ & $\begin{array}{l}90 \\
96\end{array}$ & $\begin{array}{r}95 \\
120\end{array}$ & $\begin{array}{r}85 \\
110\end{array}$ & $\begin{array}{l}80 \cdot 4 \\
99 \cdot 5^{\star}\end{array}$ \\
\hline Day temperature became normal & 6 & 4 & 4 & 4 & 5 & $t$ & $t$ & $t$ & 6 & 5 & 4.9 \\
\hline Parasitological cure & Yes & Yes & Yes & Yes & No & $t$ & $t$ & $t$ & Yes & Yes & \\
\hline $\begin{array}{l}\text { Follow up: } \\
\text { Duration (months) } \\
\text { Relapse }\end{array}$ & $\begin{array}{l}10 \\
\text { No }\end{array}$ & $\begin{array}{r}6 \\
\text { No }\end{array}$ & $\begin{array}{r}7 \\
\text { No }\end{array}$ & $\begin{array}{r}6 \\
\text { No }\end{array}$ & $\begin{array}{c}1 \\
\text { Yes }\end{array}$ & $\stackrel{t}{t}$ & $\stackrel{t}{t}$ & $\stackrel{t}{t}$ & $\begin{array}{l}3 \\
\text { No }\end{array}$ & $\begin{array}{c}2 \\
\text { No }\end{array}$ & \\
\hline
\end{tabular}

† Switched to sodium stibogluconate at end of two weeks. In these three cases post-treatment values refer to those at end of two weeks. 